\title{
Charge Transfer in Ceramic Anode for Solid Oxide Fuel Cell
}

Paulo Emílio V. de Miranda ${ }^{1}$

\author{
${ }^{1}$ Editor-in-Chief \\ Matéria Journal \\ E-mail: pmiranda@labh2.coppe.ufrj.br
}

Solid oxide fuel cells - SOFC - represent a device exceptionally efficient to generate electricity and heat. When fed with hydrogen or with reformate from the methane water vapor reforming, they possess a conventional anode that utilizes nickel oxide as electrocatalyst. Such material is being used for several years in SOFC anode composition and satisfies the main requirements for this component, especially referring to the mechanical compatibility, the chemical stability and the electronic conductivity [1]. However, other requirements are looked-for when carbonaceous fuels are to be used [2] or when multifunctional anodes are required [3]. Furthermore, the tendency nowadays is to utilize anodes with mixed conductivity, i.e., that are capable of simultaneously make the conduction of electrons and oxygen ions, which increases the dimension and the efficiency of triple phase boundaries, where the main electrochemical reactions of interest take place.

The SOFC conventional anode composed of nickel oxide on yttria stalized zirconia - YSZ - electrolyte is reduced to metallic nickel in the SOFC operation temperature. Nickel acts as electrocatalyst for the fuel oxidation, producing electrons. Due to operation problems with the device or in eventual maintenance work activities it re-oxidizes to nickel oxide. These oxy-redox cycles generate volumetric changes with the consequent cracking of the electrolyte. A solution found to this problem was to mix YSZ with nickel oxide [4].

Recently [5], the use of cerium aluminate, CeAlO3, as an electrocatalyst in SOFC anode with mixed conductivity has unveiled a similar reversible transformation to that observed for the conventional anode based on nickel oxide. Figure 1 exemplifies this behavior for the electronic conductor conventional anode, made of $\mathrm{NiO} / \mathrm{YSZ}$ when oxidized or of $\mathrm{Ni} / \mathrm{YSZ}$ when reduced, as well as for the mixed conductor ceramic anode, made of Ceria-Alumina, when in a oxidative atmosphere or of Cerium Aluminate, when in a reductive atmosphere, during the fuel cell normal operation. This reversible phase transformation mechanism of the ceramic electrocatalyst is particularly interesting due to the charge transference involved in the process, since cerium has valence +3 in the cerium aluminate and valence +4 in ceria. This is indicated in Figure 2 that shows the cerium aluminate tetragonal unit cell with the structure of the perovskite, Fig.2a, and ceria's cubic unit cell, Fig.2b. Such charge transference influences directly the material's storage capacity of oxygen ions, $\mathrm{O}^{-2}$, which is important for the kinetic of the electrochemical reactions of interest.

It was, however, verified that the power densities reached with the SOFC operation were still insufficient and that the device requires a bigger capacity for storage and release of oxygen ions. In this case, it was also proposed to mix the anode active electrocatalyst with nanometer sized YSZ particles [6]. However, the reason to make such a mixture here did not have the objective of controlling the anode's volumetric variations, such as it was done for the nickel oxide based anode. Instead, it was the possibility to form phases of the type $\mathrm{Zr}_{\mathrm{x}} \mathrm{Ce}_{1-\mathrm{x}} \mathrm{O}_{2}$, in substitution of cerium aluminate. Such $\mathrm{Zr}_{\mathrm{x}} \mathrm{Ce}_{1-\mathrm{x}} \mathrm{O}_{2}$ phases allow the activation of a charge transfer mechanism with absorption of oxygen vacancies, in which situation the cerium ion assumes valence $\mathrm{Ce}^{+4}$, and the emission of reaction species, when the cerium ion has valence $\mathrm{Ce}^{+3}$, as depicted schematically in Figure 3.

The new ceramic anode that is obtained by mixing cerium aluminate with nanometric particle size YSZ has produced phases of the type $\mathrm{Zr}_{\mathrm{x}} \mathrm{Ce}_{1-\mathrm{x}} \mathrm{O}_{2}$, in which the small zirconium ions, $\mathrm{Zr}^{+4}$, substitute the bigger diameter cerium ions, $\mathrm{Ce}^{+4}$, that contributes to increase the oxygen storage capacity and increases the kinetics of the desired electrochemical reactions in the solid oxide fuel cell.

The discussion of fundamental mechanisms that allow to understand materials behaviors in devices for applications in the energy sector are of special interest of the journal Matéria. 


\section{Solid Oxide Fuel Cell}

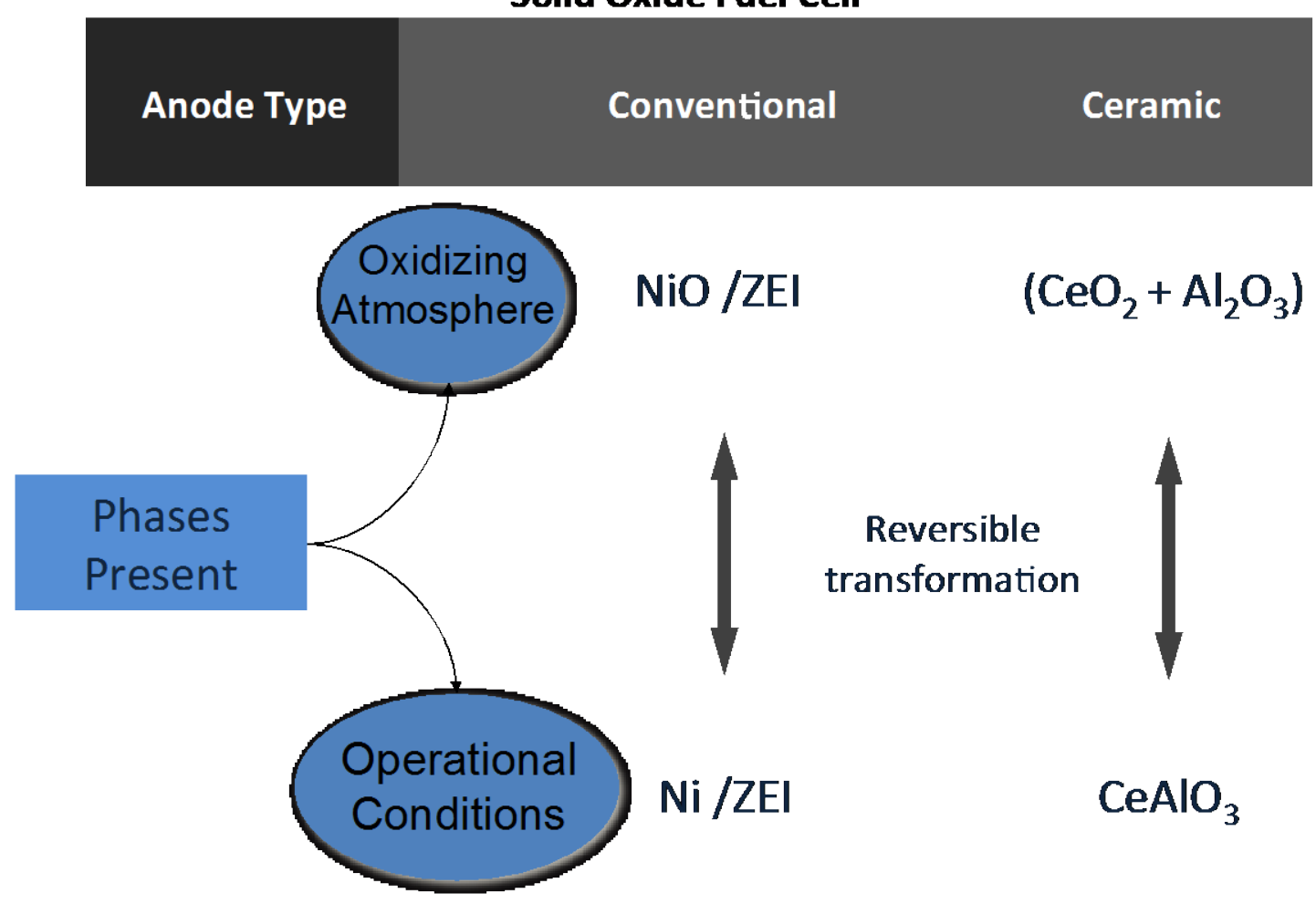

Figure 1: Reversible phase transformation in an SOFC anode: a) conventional, electronic conductor, composed of nickel oxide and yttria stabilized zirconia; b) ceramic, mixed electronic-ionic conductor, composed of cerium aluminate.

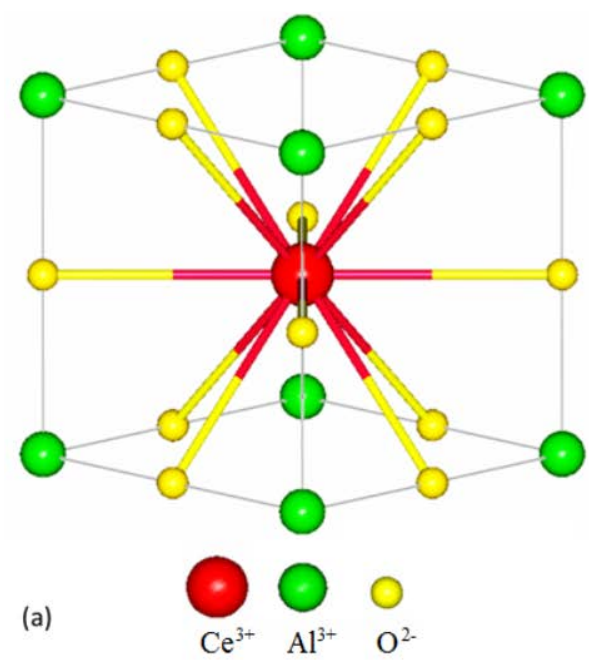

$\left(\mathrm{CeAlO}_{3}\right)$

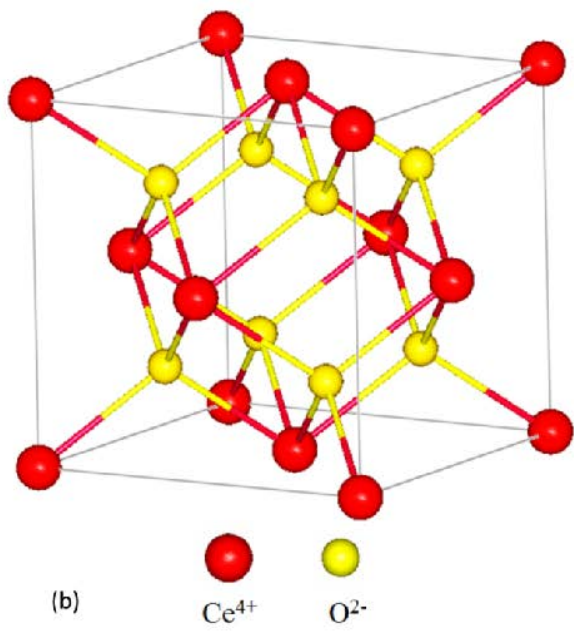

$\left(\mathrm{CeO}_{2}\right)$

Figura 2: a) Cerium aluminate's tetragonal unit cell with the structure of the perovskite ; and b) ceria's cubic unit cell, with indication of the relative positioning of ions $\mathrm{Ce}^{+3}, \mathrm{Ce}^{+4}, \mathrm{Al}^{+3}$ and $\mathrm{O}^{-2}$. 


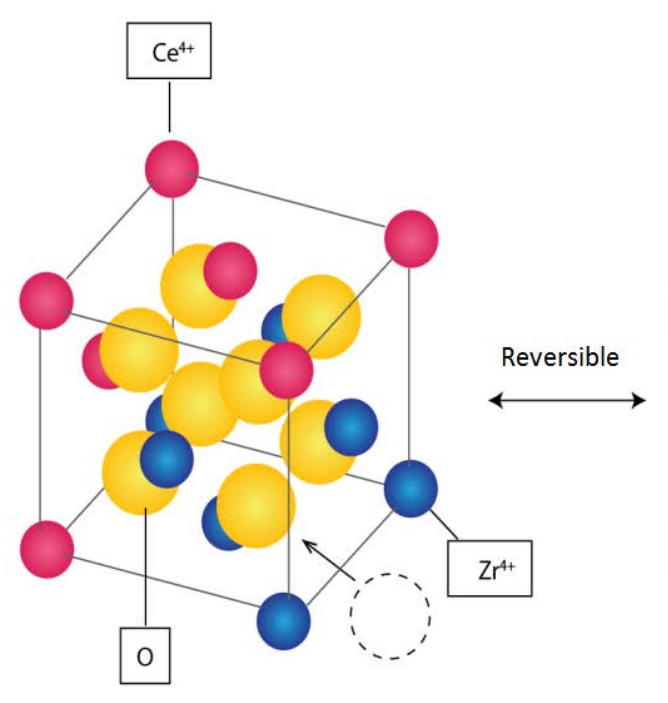

(a)

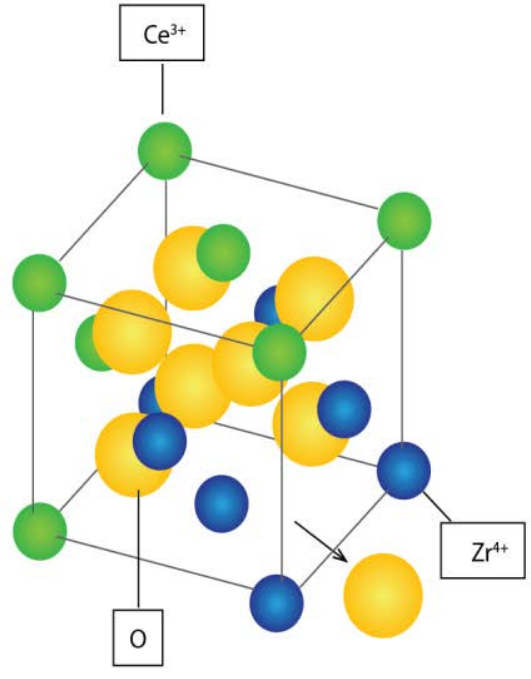

(b)

Figura 3: Charge transfer mechanism: a) with absorption of oxygen vacancies, situation in which the cerium ion assumes valence $\mathrm{Ce}^{+4}$, and $\mathrm{b}$ ) with the emission of reactions species, when the cerium ion possesses valence $\mathrm{Ce}^{+3}$.

\section{BIBLIOGRAPHY}

[1] MINH, N. Q., System technology for solid oxide fuel cells, in Fuel Cell Science and Engineering, Materials, Processes, Systems and Technology, v. 2, In: Stolten, D., Emonts, B. (eds), Weinheim, Germany, WileyVCH, pp. 963-1010, 2013.

[2] MIRANDA, P. E. V., "Materiais para um Novo Paradigma da Indústria Química”, Matéria, v.20, n.3, 2015.

[3] MIRANDA, P. E. V., "Síntese de Eletrocatalisadores Cerâmicos Nanométricos”, Matéria, v.20, n.4, pp.IIV, 2015.

[4] KLEMENSOE, T., CHUNG, C., LARSEN, P. H., et al. "The Mechanism Behind Redox Instability of Anodes in High-Temperature SOFCs", Journal of the Electrochemical Society, v.152, n.11, pp. A2186A2192, 2005.

[5] VENÂNCIO, S.A., MIRANDA, P. E. V., "Solid oxide fuel cell anode for the direct utilization of ethanol as a fuel”, Scripta Materialia, v.65, n.2, pp. 1065-1068, 2011.

[6] MIRANDA, P. E. V., VENÂNCIO, S.A., SARRUF, B. J. M., et al., "Direct Utilization of Ethanol in Solid Oxide Fuel Cells: Preparation and Characterization of CeO2-Al2O3 Based Anodes”, Presented at the 40th, International Conference and Exposition on Advanced Ceramics and Composites, Daytona Beach, Fl, USA, Jan. 24-29, 2016. 